\title{
Asthma that is unresponsive to usual care
}

\author{
Kenneth R. Chapman MD, Andrew Mclvor MD MSc
}

Previously published at www.cmaj.ca

\section{The case}

Emma is a 38-year-old woman who has had asthma since infancy. She was occasionally admitted to hospital in childhood, but her asthma became less troublesome in adolescence. She continued to need regular maintenance therapy with low-dose inhaled corticosteroids. She reported a marked worsening of her symptoms after the birth of her first child. In the past 3 years, she has used inhaled combination therapy in the form of fixed-dose salmeterol (50 mg) and fluticasone $(500 \mathrm{mg})$, taken twice daily, and has still needed quick-relief bronchodilators on average 2 or 3 times per day. She awakens with asthma symptoms about once a week and is unable to participate in fitness classes because of wheezing.

Over the past year, Emma has had 4 exacerbations for which prednisone therapy was required. One of the exacerbations was sufficiently severe to require a visit to an emergency department, but she was not admitted to hospital. At that point she was referred by her family physician to an asthma centre for further review.

$\mathrm{T}$ he total cost of asthma in Canada has been estimated at more than $\$ 500$ million annually. ${ }^{1}$ The substantial financial burden of this disease is directly linked to the failure to achieve control of the disease. Costs also increase significantly with disease severity: a small cohort of severely ill patients consumes $80 \%$ of all asthma-related health care resources. ${ }^{2,3}$ Inadequately controlled asthma accounts for more than three-quarters of related emergency department visits, admissions to hospital and unscheduled consultations with a physician, resulting in an estimated cost of $\$ 162$ million per year in Canada., ${ }^{4,5}$

Central to the management of asthma is the assessment of disease control. This is accomplished by determining the frequency of the patient's daytime and nighttime symptoms, the need for quick-relief bronchodilator therapy, limitations to physical activity, occurrence of exacerbations, and absence from work, school or usual activities. In addition to these symptom-based parameters of control, physicians should measure lung function when the patient is thought to be optimally treated. ${ }^{6}$ This will determine whether the forced expiratory volume in 1 second $\left(\mathrm{FEV}_{1}\right)$ or peak flow is normal or nearly so. These parameters are then used to categorize the patient's asthma as being controlled, partly controlled or uncontrolled, ${ }^{6}$ as described in an earlier article in this series.

\section{Key points}

- The approach to and management of severe asthma is a complex process best implemented in specialized centres.

- It is crucial to confirm the diagnosis; check inhaler technique and compliance; explore potential triggers, environmental or occupational exposures, and comorbidities; and exclude rare syndromes.

- Asthma of any severity, particularly if uncontrolled, is associated with increased morbidity and mortality.

- Therapy in severe asthma must be tailored to the individual patient and monitored regularly.

\section{Sources of information}

To identify relevant articles on omalizumab and other therapies for difficult-to-treat asthma, we performed a literature search of the "Asthma and Wheez*" register of the Cochrane Airways Group, which was originally created through a comprehensive search of EMBASE, MEDLINE and CINAHL. We searched all of the register's original research studies and reviews using the following search terms: "severe asthma," "omalizumab" and "Xolair." The current review encompasses records published in or added to the register between 2005 and June 2008. Of 783 articles retrieved, 50 were in English and provided nonduplicative clinical trial data or case reports on human asthma, adverse events, and the efficacy and safety of omalizumab and other standard and nontraditional treatments. Articles describing the use of omalizumab and other treatments for indications other than asthma were not reviewed, except for sections reporting adverse events. We performed a supplementary literature search using the following search terms: "asthma" with publication date from 2005 to 2008 and "omalizumab OR Xolair OR methotrexate OR MTX OR gold OR cyclosporin OR macrolide OR clarithromycin OR troleandomycin OR erythromycin OR josamycin OR azithromycin OR roxithromycin OR IVIG OR immunoglobulin OR immuno-globulin OR immune globulin OR thermoplasty OR Alair OR etanercept

From the Asthma and Airway Centre (Chapman), University Health Network, Toronto Western Hospital and University of Toronto, Toronto, Ont.; the Firestone Institute for Respiratory Health (Mclvor), St. Joseph's Healthcare, Hamilton, Ont.; and the Department of Medicine (Mclvor), McMaster University, Hamilton, Ont.

CMAJ 2009. DOI:10.1503/cmaj.090089 
OR Enbrel OR TNF- $\alpha$ OR TNF alpha OR necrosis." We included relevant articles from among those identified by this supplementary search $(n=184)$ in the current publication. We performed a further supplementary literature search using the following search terms: "asthma" with publication date from 1999 to 2009.

We based our grades of evidence on those of the Canadian Task Force on Preventive Health Care, ${ }^{8}$ as detailed in a previous article in this series. ${ }^{9}$

\section{Asthma control, severity and unresponsiveness}

For the majority of patients with asthma, control can be achieved with conventional therapy, and indeed some patients enjoy complete freedom from asthma symptoms using such therapy. ${ }^{10,11}$ Unfortunately, surveys in Canada and elsewhere have shown that many patients, perhaps the majority, fail to achieve adequate disease control., ${ }^{412}$ It is widely believed that this is not a consequence of intrinsically severe asthma, but rather of inadequate management, poor patient education or a combination of these 2 factors. ${ }^{413}$

A separate issue from symptom control is the definition of asthma severity. ${ }^{6,14}$ Frequent symptoms and exacerbations are not synonymous with severe disease. Patients with mild disease may have frequent symptoms or exacerbations if adequate maintenance therapy has not been prescribed or they are not taking their prescribed medications. Conversely, patients with severe disease may be free of symptoms and exacerbations if they have been given appropriate therapy. A simple guide to a patient's degree of asthma severity is the minimum amount of medication that he or she needs to maintain disease control. ${ }^{15}$

Asthma severity may change over time. Thus, it is incumbent upon physicians to reassess control regularly. Such follow-up should occur every 6 to 12 months, depending on the severity of symptoms. ${ }^{15}$ For some patients, there is no response to usual therapy. Some have no response at all to quick-relief bronchodilators or inhaled corticosteroids, whereas for others, these conventional therapies are only partially effective. Patients with these forms of refractory or difficult-to-control asthma usually receive increasingly large doses of inhaled corticosteroid with adjunctive agents but do not attain the desired levels of disease control. Ultimately, such patients are often given systemic corticosteroids, either frequently or continuously, to control or at least blunt the most severe manifestations of the disease. In this review, we consider management strategies for patients with difficult-totreat asthma.

\section{Confirming the diagnosis}

Evaluation of patients with difficult-to-treat asthma should begin with confirmation or reconfirmation of the diagnosis. A long history of disease does not in itself confirm the presence of asthma, nor does it rule out the subsequent development of cardiac or nonasthma pulmonary disease. The diagnosis of asthma requires the presence of compatible symptoms plus pulmonary function tests showing variability of airflow obstruction.

The possibility of other conditions must also be considered. Airflow obstruction that is persistent and unresponsive to bronchodilator raises the possibility of a nonasthmatic obstructive lung disease such as chronic obstructive pulmonary disease $\mathrm{e}^{16}$ or bronchiolitis obliterans. Moreover, a lack of change in airflow obstruction either over time or with more aggressive therapy increases the likelihood of such diagnoses.

Pulmonary function testing may also hint at other diagnostic possibilities. Flattening of the flow-volume loop on either the inspiratory portion or the expiratory portion or both would suggest the presence of vocal cord dysfunction. Inappropriate closure of the vocal cords on inspiration may be deliberate or unconscious and may result from vocal cord irritation. ${ }^{17}$ These problems of the vocal cords may be difficult to diagnose, and their true prevalence may be underestimated by researchers.

Plain chest radiography has little utility in the routine assessment of asthma but is helpful in ruling out other illnesses that may cause symptoms of dyspnea or cough, such as congestive heart failure.

\section{The case continued}

A specialist at the asthma centre interviews Emma and gathers the following detailed history. The patient is a lifetime nonsmoker, and no one in her household smokes. She works in a sales office where she is not exposed to any obvious occupational respiratory hazards. However, each spring she suffers from seasonal allergic rhinitis, which she treats with antihistamines or nasal corticosteroids. She does not have any pets. She experiences gastroesophageal reflux only rarely. The results of the physical examination are unremarkable except for both pallor and edema of the nasal mucosa and expiratory wheezes heard throughout the lungs. Reproducible spirometry indicates that $\mathrm{FEV}_{1}$ is $52 \%$ of predicted before and $67 \%$ of predicted after administration of inhaled bronchodilator. Additional pulmonary function testing reveals moderate gas trapping and normal diffusion capacity. Chest radiography shows flattening of the hemidiaphragms, but the results are otherwise unremarkable. Allergy skinprick testing shows moderate $(3+)$ reactions to dust and dust mite antigens and small (2+) reactions to tree and grass pollen and cat antigens. A certified asthma educator reviews the patient's inhaler technique and her general knowledge about asthma. Subsequent review of pharmacy records and inspection of the patient's inhalers are compatible with adherence to prescribed therapy.

Previous trials of adjunctive oral theophylline and montelukast and a trial of increased inhaled corticosteroid (i.e., fluticasone $500 \mu \mathrm{g}$ twice daily in addition to salmeterol [50 $\mathrm{mg}$ ] and fluticasone [500 mg] twice daily) did not alter Emma's symptom pattern. Her family physician subsequently gave her a prescription for prednisone $15 \mathrm{mg}$ daily, which resulted in partial relief of symptoms, a reduction in the need for short-acting bronchodilator to just one puff per day and improvement in prebronchodilator $\mathrm{FEV}_{1}$. However, her postbronchodilator obstruction has persisted. 


\section{Addressing nonpharmacologic aspects of care}

As outlined in previous Canadian consensus guidelines for the management of asthma, ${ }^{15}$ it is essential that all patients receive appropriate asthma education. Surveys of Canadians with asthma have revealed that many lack a rudimentary understanding of their medications and often confuse reliever medications with preventive medications. ${ }^{13}$ Furthermore, few have seen a certified asthma educator, and the vast majority do not have written action plans to guide management of exacerbations. ${ }^{14}$ Most rely on physicians or pharmacists to answer their questions about asthma, but the time and resources available for such counselling are often limited..$^{13}$ Many patients have poor inhaler technique and hence fail to achieve control of their disease.$^{18}$ Comprehensive education must include not only information about appropriate use of medications, but also the teaching and assessment of optimal inhaler technique. Even the simple-to-use dry powder inhalers can be mishandled. In addition, it is important to evaluate whether environmental factors in patients' homes or workplaces may be worsening their asthma symptoms.

Given all of these factors, hidden noncompliance may be a major factor in apparently difficult-to-control asthma. ${ }^{19}$ Pharmacy records may be helpful in estimating consumption of prescribed medication. In addition, physicians or other members of the health care team may find it useful to explore with patients their concerns about using the medications, their health beliefs, the affordability of the drugs and other common barriers to medication usage. Health care providers might also inspect a patient's inhalers to determine the prescription date and ask about the frequency of inhaler replacement to assess how often they are using inhaled controller therapies. ${ }^{20}$ Strategies to improve compliance include education, use of treatment regimens that permit a reduced dosing frequency and use of combination therapy in a single inhaler. ${ }^{21,22}$

In the home, dust mites are ubiquitous and many patients with asthma are skin-test positive to dust mite antigen. Pet dander is also an important factor in producing asthma instability. Patients who are allergic to pet dander often experience worsening of asthma during the winter months, when they spend more time indoors with their pets. The workplace is another primary source of substances that induce or worsen asthma. An estimated $10 \%$ to $20 \%$ of adults with asthma are exposed to such substances at work. ${ }^{23}$ Hence it is vital that the health care professional take an allergy history. Allergy skinprick testing will provide complementary information.

\section{Managing comorbid conditions}

Treating chronic nasal diseases is often helpful for asthma control. The simple addition of a nasal corticosteroid often improves asthma control in patients with allergic rhinitis, which is often overlooked in the context of asthma. ${ }^{24}$ Oral antihistamines have no role in the management of asthma. However, they can be used either intermittently or regularly as monotherapy in the treatment of mild allergic rhinitis or in addition to nasal inhaled corticosteroids in moderate to severe allergic rhinitis that is incompletely responsive to nasal inhaled corti- costeroids. ${ }^{25}$ The role of treating gastroesophageal reflux disease in the management of asthma is not clear; however, for patients with troublesome asthma who suffer more than occasional reflux symptoms, convincing reports have shown reduced frequency of exacerbation with use of antireflux therapies such as proton pump inhibitors. ${ }^{26}$ Obesity has been linked with a suboptimal response to inhaled agents and difficult-tocontrol asthma, but the nature and clinical implications of the association are unclear. ${ }^{27}$

\section{Screening for asthma-associated syndromes}

When asthma is difficult to treat and airflow obstruction persists after therapy, special diagnostic tests may help to determine the cause. For example, $\alpha_{1}$-antitrypsin deficiency is not uncommon in white populations and predisposes affected people to the development of premature emphysema. ${ }^{28}$ This earlyonset obstruction is commonly misdiagnosed as asthma. The average delay between the onset of symptoms and the correct diagnosis of $\alpha_{1}$-antitrypsin deficiency is about 10 years.

Patients with asthma who require oral steroids frequently or continuously may have one of the asthma syndromes in which this pattern is common. Allergic bronchopulmonary aspergillosis is reported to be present in about $13 \%$ of people who present to asthma clinics ${ }^{29}$ although its prevalence in the population has not been clearly established. This disease is characterized by difficult-to-control asthma, with frequent exacerbations, in the presence of chronic colonization by Aspergillus and a characteristic immunologic response to the fungus. Patients will typically have proximal mucous plugging and tenacious sputum. Proximal (central airway) bronchiectasis may result. Laboratory tests may reveal the presence of Aspergillus in sputum, while positive immediate skin-test responses plus positive delayed responses would suggest the dual-phase immunologic response (types I and III). Serum precipitins are typically positive for Aspergillus.

Churg-Strauss vasculitis is another variant of asthma in which steroid dependence is typical ${ }^{30}$ Before development of a vasculitic lesion of the skin or lung, an underlying vasculitis may be revealed by appropriate immunologic studies such as measurement of the titre of antineutrophil cytoplasmic antibody. In a recent population-based study, this antibody was estimated to have incidence rates of between 0 and 75 per million person-years among individuals with asthma. ${ }^{31}$

Some patients appear to have resistance to systemic corticosteroids, as demonstrated by a lack of clinical improvement with high doses of systemic steroids. Other patients have disease that is responsive to systemic steroids and show clinical improvement when these medications are administered, but their condition becomes unstable when the drugs are withdrawn. These 2 groups of patients have asthma that is described as steroid-resistant and steroid-dependent, respectively. In vitro assays have been used to define corticosteroid receptor responsiveness. However, such assays are not widely available, and the response to steroids is usually assessed clinically instead. Importantly, noncompliance with recommended oral steroids can confound such assessments; therefore, depot steroids are recommended for assessing responsiveness to steroids. ${ }^{32-34}$

Many patients with deficiency of either immunoglobulin $\mathrm{G}_{2}$ 
Box 1: Criteria for administration of omalizumab ${ }^{44,45}$

- Age $>12$ years

- Positive result on skin testing or in vivo reactivity to at least one perennial aeroallergen

- Baseline immunoglobulin E levels of $30-700 \mathrm{IU} / \mathrm{mL}$

- Weight 20-150 kg

- Calculated dose of omalizumab $<750 \mathrm{mg}$

- Severe or inadequately controlled asthma, as defined by frequent exacerbations or the need for daily or frequent oral corticosteroids, despite appropriate environmental control, smoking cessation, patient education and consistent therapy with inhaled corticosteroid at a minimum daily dose of $500 \mu \mathrm{g}$ of fluticasone or equivalent plus adjunctive therapy

or specific polysaccharide antibody have recurrent respiratory conditions, such as bronchiectasis, bronchopneumonia, bronchitis, obstructive lung disease and hyperreactive airways, any of which may present as "asthma." 35

\section{The case continued}

Several laboratory tests and other investigations are requested for Emma. Her complete blood count is normal, with no eosinophilia. The serum $\alpha_{1}$-antitrypsin level is lower than normal: 0.71 (normal range 0.8 to 1.9 ) g/L. Follow-up testing reveals an $\mathrm{MZ}$ phenotype, confirming that she is a heterozygote (carrier) for the deficiency, but with serum levels adequate to protect against premature development of emphysema. As such, no specific therapy is required. Serum levels of immunoglobulins $\mathrm{A}, \mathrm{G}$ and $\mathrm{M}$ are normal, as is immunoglobulin $\mathrm{E}$ $(120 \mathrm{IU} / \mathrm{mL})$. The erythrocyte sedimentation rate is not elevated. Tests for antineutrophil cytoplasmic antibodies and serum precipitins to common fungi, including Aspergillus spp., are negative. Sputum induction is unsuccessful. Computed tomography of the chest shows thickening of medium-sized airways and scattered nonspecific nodules, with no evidence of bronchiectasis or emphysema.

\section{Monoclonal anti-immunoglobulin E therapy}

Omalizumab is a humanized mouse monoclonal antibody that binds to circulating immunoglobulin $\mathrm{E}$, thereby rendering this moiety inactive. ${ }^{36}$ In clinical trials, omalizumab reduced symptoms and exacerbation rates among patients with atopic disease whose asthma was uncontrolled by moderate- or highdose inhaled corticosteroids with or without adjunctive longacting $\beta_{2}$-agonist therapy. Omalizumab should be dosed according to pretreatment serum total immunoglobulin $\mathrm{E}$ level and body weight, using a specified dosing table. It should be administered subcutaneously, under medical supervision, either biweeky or monthly in a clinic setting.

The majority of adverse events associated with omalizumab are minor. ${ }^{37}$ The most common dermatologic adverse events are pruritus $(2 \%)$ and dermatitis $(2 \%)$. The most common respiratory adverse effects are upper respiratory tract infection (20\%), sinusitis $(16 \%)$ and pharyngitis $(11 \%)$. The most common nervous system adverse events include headache (15\%) and dizziness (3\%). The musculoskeletal adverse effects include arthral- gia $(8 \%)$, fracture $(2 \%)$, leg pain $(4 \%)$ and arm pain $(2 \%)$. Local adverse effects related to reactions at the injection site occur in $45 \%$ of patients and include bruising, redness, warmth, burning, stinging, itching, hive formation, pain, indurations, development of a mass and inflammation. ${ }^{37}$

Reports indicate that anaphylaxis occurs in $0.09 \%$ to $0.2 \%$ of people after administration of omalizumab..$^{37,38}$ The majority of cases occur within 2 hours of administration of the medication and are most likely to occur after the first few doses. Thus the injections must be given in a medically supervised setting, with postinjection observation, and the health care providers administering the drug should be prepared to manage anaphylaxis, which can be life-threatening. ${ }^{38}$ There have been recent reports of anaphylaxis onset 2 to 24 hours or even longer after omalizumab treatment. ${ }^{39,40}$ Hence, patients should be informed of the signs and symptoms of anaphylaxis and instructed to seek immediate medical care should this problem occur.

Omalizumab costs $\$ 1200$ to $\$ 2400 /$ month (\$600 for a 150 $\mathrm{mg}$ vial). The cost-effectiveness ratio has been determined to be at least $\$ 63000$ per quality-adjusted life year, and possibly in excess of 10 times more than this. ${ }^{41,42}$ Therefore, there is considerable debate about its cost-benefit ratio. The cost can be a particular barrier for patients who have no private health insurance. The province of Quebec has reimbursed patients for the cost of omalizumab under its Exceptional Patient Program since September 2005. Governments in many European countries, the United States and the United Kingdom also reimburse patients for omalizumab. A committee of the UK National Health Service's National Institute for Health and Clinical Excellence concluded in 2007 that, for a narrowly defined group of people who are severely affected by asthma, use of omalizumab as add-on therapy can be cost-effective, provided that therapy is discontinued after 16 weeks if there is no response and that vial wastage is minimized. ${ }^{43}$

Omalizumab therapy should be considered for patients with severe asthma who require frequent or constant oral steroids despite continuous therapy with inhaled steroids and adjunctive therapy and who meet the criteria listed in Box 1.44,45 Very high levels of serum immunoglobulin E preclude treatment with omalizumab; in such patients, it is impossible to administer sufficient monoclonal therapy to bind more than $95 \%$ of the circulating immunoglobulin and hence have an effect.

Before therapy with omalizumab is initiated, the patient should be assessed by a specialist. The response to omalizumab should be evaluated at 6 months and therapy discontinued for those who have not benefited. There is currently insufficient evidence to recommend omalizumab therapy for children with asthma (less than 12 years of age).

\section{Other therapies for severe asthma unresponsive to usual care}

Many other therapies have been used to treat severe or refractory asthma (Table 1). ${ }^{46-89}$ However, none of them is currently considered a well-established therapy that can be recommended at this time. Several such interventions were tested in an era when higher-dose inhaled corticosteroid therapy with 
Table 1: Other treatments for severe asthma

\begin{tabular}{|c|c|c|c|c|c|}
\hline $\begin{array}{l}\text { Therapy or therapeutic } \\
\text { agent }\end{array}$ & $\begin{array}{c}\text { Mode of } \\
\text { administration }\end{array}$ & Dosage & $\begin{array}{l}\text { Quality of } \\
\text { evidence, } \\
\text { level* }\end{array}$ & Costt & Principal adverse effects \\
\hline Methotrexate ${ }^{46-50}$ & Oral & $\begin{array}{l}5-25 \mathrm{mg} / \mathrm{wk} \text {, in a } \\
\text { single dose }\end{array}$ & 1 & $\$$ & $\begin{array}{l}\text { Anemia, diarrhea, nausea, } \\
\text { vomiting, leukopenia, } \\
\text { hepatic fibrosis, pulmonary } \\
\text { toxicity, opportunistic } \\
\text { infections }\end{array}$ \\
\hline Cyclosporin $A^{51,52}$ & Oral & $\begin{array}{l}3 \mathrm{mg} / \mathrm{kg} \text { twice daily, } \\
\text { with target trough } \\
\text { serum concentration } \\
\text { of } 150 \mathrm{mg} / \mathrm{L}\end{array}$ & 1 & $\$ \$ \$$ & $\begin{array}{l}\text { Hypertension, renal failure, } \\
\text { hypertrichosis, parasthesia }\end{array}$ \\
\hline Auranofin (gold salt) ${ }^{53,54}$ & Oral & $3 \mathrm{mg}$ twice daily & II-2 & $\$ \$$ & $\begin{array}{l}\text { Urticaria, stomatitis, } \\
\text { leukopenia, } \\
\text { thrombocytopenia, } \\
\text { proteinuria }\end{array}$ \\
\hline $\begin{array}{l}\text { Intravenous } \\
\text { immunoglobulin }{ }^{55-59}\end{array}$ & Intravenous & $\begin{array}{l}4 \text { doses }(1 \mathrm{~g} / \mathrm{kg} \text { body } \\
\text { weight): first } 2 \text { doses } \\
\text { on consecutive days, } \\
\text { subsequent doses } \\
\text { once every } 4 \text { wks }\end{array}$ & 1 & $\$ \$ \$$ & $\begin{array}{l}\text { Aseptic meningitis syndrome, } \\
\text { thromboembolic events, } \\
\text { renal impairment, hemolytic } \\
\text { anemia }\end{array}$ \\
\hline $\begin{array}{l}\text { Diaminodiphenyl } \\
\text { sulfone (dapsone) }\end{array}$ & Oral & 100 mg twice daily & $\mathrm{II}-2$ & $\$$ & $\begin{array}{l}\text { Methemoglobinemia, } \\
\text { hypersensitivity reactions, } \\
\text { agranulocytosis, peripheral } \\
\text { neuritis, psychosis }\end{array}$ \\
\hline Hydroxychloroquine $^{61}$ & Oral & $300-400 \mathrm{mg} / \mathrm{d}$ & II-2 & $\$$ & $\begin{array}{l}\text { Hypersensitivity, liver and } \\
\text { renal toxicity, blood } \\
\text { dyscrasias }\end{array}$ \\
\hline Anti-interleukin $5^{62-66}$ & Intravenous & $\begin{array}{l}750 \text { mg, given } \\
\text { monthly }\end{array}$ & II-2 & $\begin{array}{l}\text { NA (not yet approved } \\
\text { or marketed in Canada) }\end{array}$ & $\begin{array}{l}\text { None of significance; local } \\
\text { reactions at injection site }\end{array}$ \\
\hline Anti-interleukin $12^{67}$ & Subcutaneous & $\begin{array}{l}\text { Weekly injections of } \\
\text { increasing dose: } 0.1 \text {, } \\
0.25,0.5 \mu \mathrm{g} / \mathrm{kg}\end{array}$ & II-2 & $\begin{array}{l}\text { NA (not yet approved } \\
\text { or marketed in Canada) }\end{array}$ & $\begin{array}{l}\text { None of significance; local } \\
\text { reactions at injection site }\end{array}$ \\
\hline $\begin{array}{l}\text { Bronchial } \\
\text { thermoplasty }^{68-71}\end{array}$ & $\begin{array}{l}\text { Invasive } \\
\text { bronchoscopic } \\
\text { procedure }\end{array}$ & Several serial sessions & II-2 & $\begin{array}{l}\text { NA (not available } \\
\text { outside of clinical trials) }\end{array}$ & $\begin{array}{l}\text { Short-term increase in cough } \\
\text { and wheeze }\end{array}$ \\
\hline Homeopathy ${ }^{72-75}$ & NA & $\begin{array}{l}\text { According to } \\
\text { individual patient } \\
\text { characteristics }\end{array}$ & III-3 & $\$ \$$ & Variable \\
\hline Chiropractic $^{76}$ & NA & $\begin{array}{l}\text { According to } \\
\text { individual patient } \\
\text { characteristics }\end{array}$ & III-3 & $\$ \$$ & Variable \\
\hline Acupuncture $^{75,77}$ & NA & $\begin{array}{l}\text { According to } \\
\text { individual patient } \\
\text { characteristics }\end{array}$ & II-2 & $\$ \$$ & Variable \\
\hline $\begin{array}{l}\text { Hypnosis }^{78} \text { and } \\
\text { relaxation }^{79}\end{array}$ & NA & $\begin{array}{l}\text { According to } \\
\text { individual patient } \\
\text { characteristics }\end{array}$ & III-3 & $\$ \$$ & None reported \\
\hline $\begin{array}{l}\text { Herbal medicine }{ }^{80,81} \\
\text { Chinese medicine }^{82} \text { and } \\
\text { ayurvedic medicine }^{81}\end{array}$ & NA & $\begin{array}{l}\text { According to } \\
\text { individual patient } \\
\text { characteristics }\end{array}$ & III-3 & $\$ \$$ & Variable \\
\hline Breathing exercises ${ }^{83-86}$ & NA & $\begin{array}{l}\text { According to } \\
\text { individual patient } \\
\text { characteristics }\end{array}$ & II-2 & NA & None reported \\
\hline $\begin{array}{l}\text { Supplementation (e.g., } \\
\text { vitamin C, vitamin E, } \\
\text { magnesium, fish oil) }\end{array}$ & NA & $\begin{array}{l}\text { According to } \\
\text { individual patient } \\
\text { characteristics }\end{array}$ & III-3 & $\$ \$$ & None reported \\
\hline
\end{tabular}

Note: NA = not applicable.

*As defined by Kaplan et al. ${ }^{9}$ (based on Canadian Task Force for Preventive Health Care ${ }^{8}$ ).

$\dagger \$=$ very inexpensive, $\$ \$=$ moderately expensive, $\$ \$ \$=$ expensive. 
or without long-acting $\beta_{2}$-agonists was not available; as such, positive findings from older studies are of questionable relevance in contemporary practice. Methotrexate, gold and cyclosporin A have corticosteroid-sparing effects clinically that must be weighed against a serious adverse effect profile. ${ }^{46-54}$ For example, low-dose oral methotrexate therapy, widely used in the treatment of rheumatologic diseases, has

\section{Box 2: Key messages for treatment of asthma} unresponsive to usual care

- Patients should be referred to a specialist or to a centre specializing in asthma care when symptoms or exacerbations persist despite administration of moderateto high-dose inhaled corticosteroids plus adjunctive therapy, such as long-acting $\beta_{2}$-agonists (grade $A$ recommendation; level II-2 evidence).

- Evaluating difficult-to-treat asthma includes a return to the basic principles of asthma management. The treating physician must use objective lung-function testing. The diagnosis is confirmed when such testing demonstrates variable airflow obstruction. Lack of variability in airflow obstruction might suggest chronic obstructive pulmonary disease or another nonasthmatic obstructive process. Nonreproducibility of the spirometry findings or flattening of the flow-volume loop might suggest functional illness or vocal cord dysfunction (grade A recommendation; level I evidence).

- Common causes of refractory asthma include exposure to tobacco smoke, continued exposure to a potent allergen such as a family pet, and irritants or inducers of workplace related asthma. Physicians caring for such patients must take a careful history, paying particular attention to these elements (grade A recommendation; level I evidence).

- Physicians should attempt to assess patient compliance with prescribed therapy and any barriers to compliance. Noncompliance with prescribed therapy is a common reason for poor asthma control and cannot be predicted by demographic characteristics (grade B recommendation; level II-2 evidence).

- Physicians should request determination of serum $\alpha_{1}{ }^{-}$ antitrypsin level for patients with asthma when airflow limitation persists following treatment (grade B recommendation; level II-2 evidence).

- If a patient requires systemic corticosteroids frequently or continuously, the physician should consider severe asthma variants such as allergic bronchopulmonary aspergillosis or Churg-Strauss vasculitis (grade B recommendation; level II-2 evidence).

- Physicians may consider a trial of omalizumab for patients with severe asthma who require continuous or frequent oral steroids despite optimal inhaled therapy and who are able to pay for the medication through direct payment or private insurance or who are eligible for a reimbursement program. Its use may be associated with reduced frequency of exacerbations, improved symptom control and improved quality of life. The response to therapy should be evaluated after 6 months, at which time the decision to continue or discontinue therapy should be made (grade B recommendation; level I evidence).

- Many anti-inflammatory medications have been explored in asthma, as have alternative medications and therapies. Currently, there is insufficient evidence to recommend these alternative approaches (grade I recommendation; level III evidence). been reported to reduce the need for systemic corticosteroids in severe asthma, but study results have been inconsistent. ${ }^{46-50}$ A few patients have been reported to benefit from oral gold therapy, ${ }^{53,54}$ and intravenous immunoglobulin has been reported to be of benefit, but only in uncontrolled studies. ${ }^{55-59}$

Dapsone $^{60}$ and hydroxychloroquine ${ }^{61}$ also have not shown robust effects in studies. A relatively new treatment, the interleukin-5-blocking monoclonal antibody mepolizumab, is showing promise in preliminary randomized studies, but large randomized trials have not yet been published. ${ }^{62-66}$ An interleukin-12-blocking agent has not yet shown efficacy against severe asthma. ${ }^{67}$

Other studies have examined whether antibiotics have a role to play in the treatment of refractory asthma. For example, troleandomycin has been reported to reduce the need for oral steroids in patients with oral-steroid-dependent asthma, but is thought to do so by altering the metabolism of the oral steroids. ${ }^{90}$

In the contemporary literature, conflicting findings have been reported for the use of antitumour necrosis factor $\alpha$ drugs such as etanercept or infliximab. ${ }^{91}$ Further study is required.

Bronchial thermoplasty is a recently developed invasive procedure performed during serial bronchoscopic sessions, each lasting about 30 minutes, in which radiofrequency ablation is used to destroy bronchial smooth muscle, with the goal of reducing airflow variability. ${ }^{68}$ The procedure is accompanied by a short-term increase in cough and wheeze, but over the ensuing weeks and months, patients with moderate to severe asthma experience improvement in various asthma outcomes. ${ }^{69-71}$ However, respirologists and primary care physicians who treat patients with refractory asthma are awaiting results from long-term, controlled trials in patients with more severe or difficult-to-treat asthma. The intervention is currently not available outside of clinical trials.

Several therapeutic agents are under development for mild, moderate, severe and refractory asthma. In particular, specific target sites are being studied for the subsequent development of novel drug classes. The identification of ADAM33 (a disintegrase and metalloprotease 33 gene) as a major risk factor in the pathogenesis of bronchial hyperresponsiveness and airway wall remodelling provides insight into the pathogenesis of asthma and represents a novel therapeutic target for drug development. ${ }^{92}$

Many patients with severe asthma also turn to alternative medicine. The approaches range from chiropractic to breathing exercises. There is a paucity of studies of these treatments, but to date the evidence indicates that none are efficacious (Table 1). ${ }^{72-89}$

\section{Outcome of the case}

Emma is treated every 4 weeks with supervised omalizumab injections at a dosage estimated from the treatment monograph on the basis of her weight $(70 \mathrm{~kg})$ and initial immunoglobulin E level: 2 subcutaneous injections of $150 \mathrm{mg}$ each for a total of $300 \mathrm{mg}$ at each visit. After 3 months of this therapy, Emma is no longer experiencing exacerbations. The dosage of prednisone is reduced to $10 \mathrm{mg}$ per day, although the patient continues daily use of a quick-relief bronchodilator. After 3 more months, she uses bronchodilator relief no 
more than twice weekly and no longer uses prednisone. Spirometry shows only mild airflow limitation and reveals that the level of gas trapping has been reduced.

\section{Conclusions}

The key messages for the management of uncontrolled asthma are presented in Box 2. The approach to and management of severe asthma is a complex process best implemented in specialized centres. Fortunately, although rates of morbidity and utilization of health care services are high, the number of people with very severe or difficult-to-treat asthma in Canada is relatively small. Currently, omalizumab seems to be a safe, well-tolerated addition to the armamentarium for suitable, carefully selected patients with severe, atopic asthma.

This article has been peer reviewed.

Competing interests: Kenneth Chapman has received compensation for consulting with AstraZeneca, Boehringer-Ingelheim, CSL Behring, GlaxoSmithKline, Merck Frosst, Novartis, Nycomed, Pfizer, Roche, Schering Plough and Talecris. He has undertaken research funded by AstraZeneca, BoehringerIngelheim, CSL Behring, Forest Labs, GlaxoSmithKline, Novartis, Parangenix, Roche and Talecris. He has participated in continuing medical education activities sponsored in whole or in part by AstraZeneca, Boehringer-Ingelheim, GlaxoSmithKline, Merck Frosst, Novartis, Nycomed, Pfizer and Talecris Andrew McIvor has attended advisory board meetings and provided continuing medical education for which he has received honoraria from pharmaceutical companies involved in asthma management: AstraZeneca, BoehringerIngelheim, Graceway, GlaxoSmithKlein, Novartis, Merck Frosst and Pfizer.

Contributors: Both authors contributed to the development, writing and editing of the article, and both approved the final version to be published.

Funding: The Canadian Thoracic Society has received funding to facilitate the knowledge translation activities of the CTS Asthma Committee from AstraZeneca Canada, GlaxoSmithKline Inc., Merck Frosst Canada and Novartis Pharmaceuticals. None of the sponsors played a role in the collection, review, analysis or interpretation of the scientific literature or in any decisions regarding the key messages presented in the case studies.

\section{REFERENCES}

1. Krahn MD, Berka C, Langlois P, et al. Direct and indirect costs of asthma in Canada. CMAJ 1996;154:821-31.

2. Ungar WJ, Coyte PC, Chapman KR, et al.; Pharmacy Medication Monitoring Program Advisory Board. The patient level cost of asthma in adults in south centra Ontario. Can Respir J 1998:5:463-71.

3. Smith DH, Malone DC, Lawson KA, et al. A national estimate of the economic costs of asthma. Am J Respir Crit Care Med 1997;156:787-93.

4. Chapman KR, Ernst P, Grenville A, et al. Control of asthma in Canada: failure to achieve guideline targets. Can Respir J 2001;8(Suppl A):35A-40A

5. Seung SJ, Mittmann N. Urgent care costs of uncontrolled asthma in Canada, 2004. Can Respir J 2005; 12:435-6.

6. Bateman ED, Hurd SS, Barnes PJ, et al. Global strategy for asthma management and prevention. GINA executive summary. Eur Respir J 2008;31:143-78.

7. Balter MS, Bell AD, Kaplan AG, et al. Management of asthma in adults. CMAJ 2009. DOI:10.1503/cmaj.080007.

8. Canadian Task Force on Preventive Health Care. New grades for recommendations from the Canadian Task Force on Preventive Health Care. CMAJ 2003;169:207-8.

9. Kaplan AG, Balter MS, Bell AD, et al. Diagnosis of asthma in adults. CMAJ 2009 DOI:10.1503/cmaj.080006.

10. Bateman ED, Boushey HA, Bousquet J, et al. Can guideline-defined asthma control be achieved? The Gaining Optimal Asthma ControL study. Am J Respir Crit Care Med 2004;170:836-44.

11. Boulet LP, Becker A, Bérubé D, et al.; Canadian Asthma Consensus Group. Canadian asthma consensus report, 1999. CMAJ 1999;161(Suppl 11):S1-5.

12. Rabe KF, Adachi M, Lai CKW, et al. Worldwide severity and control of asthma in children and adults: the global asthma insights and reality surveys. J Allergy Clin Immunol 2004;114:40-7.

13. Fitzgerald JM, Boulet LP, McIvor RA, et al. Asthma control in Canada remains suboptimal: The Reality of Asthma Control (TRAC) study. Can Respir J 2006;13:253-9.
14. Chapman KR. Impact of 'mild' asthma on health outcomes: findings of a systematic search of the literature. Respir Med 2005;99:1350-62.

15. Lemiere C, Bai T, Balter M, et al. Adult asthma consensus guidelines update 2003 Can Respir J 2004;11(Suppl A):9A-18A.

16. O'Donnell DE, Aaron S, Bourbeau J, et al. Canadian Thoracic Society recommendations for management of chronic obstructive pulmonary disease -2003. Can Respir J 2003;10(Suppl A):11A-65A

17. Newman KB, Mason UG 3rd, Schmaling KB. Clinical features of vocal cord dysfunction. Am J Respir Crit Care Med 1995;152:1382-6.

18. Dolovich MB, Ahrens RC, Hess DR, et al. Device selection and outcomes of aerosol therapy: evidence-based guidelines: American College of Chest Physicians/American College of Asthma, Allergy, and Immunology. Chest 2005;127:335-71.

19. Rand CS, Wise RA. Measuring adherence to asthma medication regimens. Am J Respir Crit Care Med 1994;149(Suppl):S69-76.

20. Walewski KM, Cicutto L, D'Urzo AD, et al. Evaluation of a questionnaire to assess compliance with anti-asthma medications. J Asthma 2004;41:77-83.

21. Stoloff SW, Stempel DA, Meyer J, et al. Improved refill persistence with fluticasone propionate and salmeterol in a single inhaler compared with other controller therapies. J Allergy Clin Immunol 2004;113:245-51.

22. Chapman KR, Walker L, Cluley S, et al. Improving patient compliance with asthma therapy. Respir Med 2000;94:2-9.

23. Blanc PD, Toren K. How much adult asthma can be attributed to occupational factors? Am J Med 1999;107:580-7.

24. Scadding GK. Other anti-inflammatory uses of intranasal corticosteroids in upper respiratory inflammatory diseases. Allergy 2000;55(Suppl 62):19-23.

25. Bousquet J, Van-Cauwenberge P, Khaltaev N; ARIA Workshop Group. Allergic rhinitis and its impact on asthma. J Allergy Clin Immunol 2001;108(Suppl 5):S147-334.

26. Littner MR, Leung FW, Ballard ED, et al. Effects of 24 weeks of lansoprazole therapy on asthma symptoms, exacerbations, quality of life, and pulmonary function in adult asthmatic patients with acid reflux symptoms. Chest 2005;128:1128-35.

27. Boulet LP, Des CA. The link between obesity and asthma: a Canadian perspective. Can Respir J 2007;14:217-20.

28. Stoller JK, Snider GL, Brantly ML, et al. Genetic testing for alpha-1 antitrypsin deficiency - ethical, legal, psychologic, social, and economic issues. Am J Respir Crit Care Med 2003;168:874-96.

29. Agarwal R. Allergic bronchopulmonary aspergillosis. Chest 2009;135:805-26.

30. Grau RG. Churg-Strauss syndrome: 2005-2008 update. Curr Rheumatol Rep 2008; 10:453-8

31. Harrold LR, Andrade SE, Go AS, et al. Incidence of Churg-Strauss syndrome in asthma drug users: a population-based perspective. J Rheumatol 2005;32:1076-80.

32. Nimmagadda SR, Spahn JD, Leung DYM, et al. Steroid-resistant asthma: evaluation and management. Ann Allergy Asthma Immunol 1996;77:345-55.

33. Peake MD, Cayton RM, Howard P. Triamcinolone in corticosteroid-resistant asthma. Br J Dis Chest 1979;73:39-44.

34. Corrigan CJ, Brown PH, Barnes NC, et al. Glucocorticoid resistance in chronic asthma: glucocorticoid pharmacokinetics, glucocorticoid receptor characteristics, and inhibition of peripheral blood $\mathrm{T}$ cell proliferation by glucocorticoids in vitro. Am Rev Respir Dis 1991;144:1016-25.

35. Loftus BG, Price JF, Lobo-Yeo A, Vergani D. IgG subclass deficiency in asthma Arch Dis Child 1988:63:1434-7.

36. Chapman KR, Cartier A, Hebert J, et al. The role of omalizumab in the treatment of severe allergic asthma. Can Respir J 2006;13(Suppl B):1B-9B.

37. Corren J, Casale TB, Lanier B, et al. Safety and tolerability of omalizumab. Clin Exp Allergy 2009;39:788-97.

38. Cox L, Platts-Mills TA, Finegold I, et al. American Academy of Allergy, Asthma \& Immunology/American College of Allergy, Asthma and Immunology Joint Task Force report on omalizumab-associated anaphylaxis. J Allergy Clin Immunol 2007; 120:1373-7.

39. Barry PJ, O'Mahony A, Finnegan C, et al. Delayed allergic reactions to omalizumab: Are patients reporting all cases? J Allergy Clin Immunol 2008;121:785-6.

40. Limb SL, Starke PR, Lee CE, et al. Delayed onset and protracted progression of anaphylaxis after omalizumab administration in patients with asthma. J Allergy Clin Immunol 2007;120:1378-81

41. CEDAC final recommendation on reconsideration and reasons for recommendation: omalizumab. Ottawa (ON): Canadian Coordinating Office for Technology Assessment; 2006. Available: www.cadth.ca/media/cdr/complete/cdr_complete Xolair_March7-06.pdf (accessed 2009 Jul. 30).

42. Wu AC, Paltiel AD, Kuntz KM, et al. Cost-effectiveness of omalizumab in adults with severe asthma: results from the Asthma Policy Model. J Allergy Clin Immunol 2007; 120:1146-52

43. Omalizumab for severe persistent allergic asthma. London (UK): National Health Service, National Institute for Health and Clinical Excellence; 2007 Available: www.nice.org.uk/nicemedia/pdf/TA133Guidance.pdf (accessed 2009 Jul. 30).

44. Fanta CH. Asthma. N Engl J Med 2009;360:1002-14

45. Chapman KR, Cartier A, Hébert J, et al. The role of omalizumab in the treatment of severe allergic asthma. Can Respir J 2006;13(Suppl B):1B-9B.

46. Dyer PD, Vaughan TR, Weber RW. Methotrexate in the treatment of steroiddependent asthma. J Allergy Clin Immunol 1991;88:208-12.

47. Coffey MJ, Sanders G, Eschenbacher WL, et al. The role of methotrexate in the management of steroid-dependent asthma. Chest 1994;105:117-21.

48. Stewart GE 2nd, Diaz JD, Lockey RF, et al. Comparison of oral pulse methotrexate with placebo in the treatment of severe glucocorticosteroid-dependent asthma. $J$ Allergy Clin Immunol 1994;94:482-9. 
49. Marin MG. Low-dose methotrexate spares steroid usage in steroid-dependent asthmatic patients: a meta-analysis. Chest 1997;112:29-33.

50. Shulimzon TR, Shiner RJ. A risk-benefit assessment of methotrexate in corticosteroid-dependent asthma. Drug Saf 1996;15:283-90.

51. Alexander AG, Barnes NC, Kay AB. Trial of cyclosporin in corticosteroid-dependent chronic severe asthma. Lancet 1992;339:324-8.

52. Lock SH, Kay AB, Barnes NC. Double-blind, placebo-controlled study of cyclosporin A as a corticosteroid-sparing agent in corticosteroid-dependent asthma. Am J Respir Crit Care Med 1996;153:509-14.

53. Bernstein IL, Bernstein DI, Dubb JW, et al. A placebo-controlled multicenter study of auranofin in the treatment of patients with corticosteroid-dependent asthma. $J$ Allergy Clin Immunol 1996;98:317-24.

54. Nierop G, Gijzel WP, Bel EH, et al. Auranofin in the treatment of steroid-dependent asthma: a double-blind study. Thorax 1992;47:349-54

55. Mazer BD, Gelfand EW. An open-label study of high-dose intravenous immunoglobulin in severe childhood asthma. J Allergy Clin Immunol 1991;87: 976-83.

56. Jakobsson T, Croner S, Kjellman NI, et al. Slight steroid-sparing effect of intravenous immunoglobulin in children and adolescents with moderately severe bronchial asthma. Allergy 1994;49:413-20.

57. Niggemann B, Leupold W, Schuster A, et al. Prospective, double-blind, placebocontrolled, multicentre study on the effect of high-dose, intravenous immunoglobulin in children and adolescents with severe bronchial asthma. Clin Exp Allergy 1998;28:205-10.

58. Landwehr LP, Jeppson JD, Katlan MG, et al. Benefits of high-dose i.v. immunoglobulin in patients with severe steroid-dependent asthma. Chest 1998; 114:1349-56.

59. Vrugt B, Wilson S, van Velzen E, et al. Effects of high-dose intravenous immunoglobulin in two severe corticosteroid insensitive asthmatic patients. Thorax 1997;52:662-4.

60. Berlow BA, Liebhaber M, Dyer Z, et al. The effect of dapsone in steroid-dependent asthma. J Allergy Clin Immunol 1991;87:710-5.

61. Charous BL. Open study of hydroxychloroquine in the treatment of severe symptomatic or corticosteroid-dependent asthma. Ann Allergy 1990;65:53-8.

62. Leckie MJ, ten Brinke A, Khan J, et al. Effects of an interleukin-5 blocking monoclonal antibody on eosinophils, airway hyper-responsiveness, and the late asthmatic response. Lancet 2000;356:2144-8.

63. Nair P, Pizzichini MM, Kjarsgaard M, et al. Mepolizumab for prednisone-dependent asthma with sputum eosinophilia. N Engl J Med 2009;360:985-93.

64. Haldar P, Brightling CE, Hargadon B, et al. Mepolizumab and exacerbations of refractory eosinophilic asthma. N Engl J Med 2009;360:973-84.

65. Flood-Page P, Swenson C, Faiferman I, et al.; International Mepolizumab Study Group. A study to evaluate safety and efficacy of mepolizumab in patients with moderate persistent asthma. Am J Respir Crit Care Med 2007;176:1062-71.

66. Mepolizumab: 240563, anti-IL-5 monoclonal antibody - GlaxoSmithKline, antiinterleukin-5 monoclonal antibody - GlaxoSmithKline, SB 240563. Drugs $R D$ 2008;9:125-30.

67. Bryan SA, O'Connor BJ, Matti S, et al. Effects of recombinant human interleukin12 on eosinophils, airway hyper-responsiveness, and the late asthmatic response. Lancet 2000;356:2149-53.

68. Cox G, Miller J, Mitzner W, et al. Radiofrequency ablation of airway smooth muscle for sustained treatment of asthma: rationale and preliminary investigations. Eur Respir J 2004;24:659-63.

69. Cox PG, Miller JD, McWilliams A, et al. Bronchial thermoplasty for asthma. Am J Respir Crit Care Med 2006;173:965-9.

70. Pavord ID, Cox G, Thomson NC, et al. Safety and efficacy of bronchial thermoplasty in symptomatic, severe asthma. Am J Respir Crit Care Med 2007;176:1185-91.

71. Cox G, Thomson NC, Rubin AS, et al. Asthma control during the year after bronchial thermoplasty. N Engl J Med 2007;356:1327-37.

72. McCarney RW, Linde K, Lasserson TJ. Homeopathy for chronic asthma [review] Cochrane Database Syst Rev 2004:(1):CD000353.

73. White $\mathrm{A}$, Slade $\mathrm{P}$, Hunt $\mathrm{C}$, et al. Individualised homeopathy as an adjunct in the treatment of childhood asthma: a randomised placebo controlled trial. Thorax 2003;58:317-21.

74. Lewith GT, Watkins AD, Hyland ME, et al. Use of ultramolecular potencies of allergen to treat asthmatic people allergic to house dust mite: double blind randomised controlled clinical trial. BMJ 2002;324:520.

75. McCarney RW, Lasserson TJ, Linde K, et al. An overview of two Cochrane systematic reviews of complementary treatments for chronic asthma: acupuncture and homeopathy. Respir Med 2004;98:687-96.

76. Hondras MA, Linde K, Jones AP. Manual therapy for asthma [review]. Cochrane Database Syst Rev 2005;(2):CD001002.

77. Martin J, Donaldson AN, Villarroel R, et al. Efficacy of acupuncture in asthma: systematic review and meta-analysis of published data from 11 randomised controlled trials. Eur Respir J 2002;20:846-52.
78. Brown D. Evidence-based hypnotherapy for asthma: a critical review. Int J Clin Exp Hypn 2007;55:220-49.

79. Huntley A, White AR, Ernst E. Relaxation therapies for asthma: a systematic review. Thorax 2002;57:127-31

80. Arnold E, Clark CE, Lasserson TJ, et al. Herbal interventions for chronic asthma in adults and children [review]. Cochrane Database Syst Rev 2008;(1):CD005989.

81. Singh BB, Khorsan R, Vinjamury SP, et al. Herbal treatments of asthma: a systematic review. J Asthma 2007;44:685-98.

82. Li XM, Brown L. Efficacy and mechanisms of action of traditional Chinese medicines for treating asthma and allergy. J Allergy Clin Immunol 2009;123:297-306.

83. Price D, Pavord I. Breathing exercises for asthma: a randomised controlled trial Thorax 2009; 64:55-61.

84. Cowie RL, Conley DP, Underwood MF, et al. A randomised controlled trial of the Buteyko technique as an adjunct to conventional management of asthma. Respir Med 2008;102:726-32.

85. Cooper S, Oborne J, Newton S, et al. Effects of two breathing exercises (buteyko and pranayama) in asthma: a randomised controlled trial. Thorax 2003;58:674-9.

86. Holloway E, Ram FS. Breathing exercises for asthma [review]. Cochrane Database Syst Rev 2004;(1):CD001277.

87. Woods RK, Thien FC, Abramson JM. Dietary marine fatty acids (fish oil) for asthma in adults and children [review]. Cochrane Database Syst Rev 2002;(3): CD001283.

88. Kaur B, Rowe BH, Arnold E. Vitamin C supplementation for asthma [review] Cochrane Database Syst Rev 2009;(1):CD000993.

89. Fogarty A, Lewis SA, Scrivener SL, et al. Oral magnesium and vitamin C supplements in asthma: a parallel group randomized placebo-controlled trial. Clin Exp Allergy 2003;33:1355-9

90. Nelson HS, Hamilos DL, Corsello PR, et al. A double-blind study of troleandomycin and methylprednisolone in asthmatic subjects who require daily corticosteroids. Am Rev Respir Dis 1993;147:398-404.

91. Howarth PH, Babu KS, Arshad HS, et al. Tumour necrosis factor (TNFalpha) as a novel therapeutic target in symptomatic corticosteroid dependent asthma. Thorax 2005;60:1012-8.

92. Puxeddu I, Pang YY, Harvey A, et al. The soluble form of a disintegrin and metalloprotease 33 promotes angiogenesis: implications for airway remodeling in asthma. J Allergy Clin Immunol 2008;121:1400-6.et

Correspondence to: Dr. Kenneth R. Chapman, Asthma and Airway Centre, University Health Network, Toronto Western Hospital, Rm. 7-451 East Wing, 399 Bathurst St., Toronto ON M5T 2S8; kchapman@ca.inter.net

This article is the fourth in a 7-part case study series that was developed as a knowledge translation initiative of the Canadian Thoracic Society Asthma Committee. The series aims to educate and inform primary care providers and nonrespiratory specialists about the diagnosis and management of asthma. The key messages presented in the cases are not clinical practice guidelines but are based on a review of the most recent scientific evidence available. Financial support for the publication of this series has been provided, in part, by the Canadian Thoracic Society.

\section{Articles to date in this series}

- Subbarao P, Mandhane PJ, Sears MR. Asthma: epidemiology, etiology and risk factors. CMAJ www.cmaj.ca/cgi/doi/10.1503/cmaj.080612

- Kaplan A, Balter M, Bell A, et al. Diagnosis of asthma in adults. CMAJ www.cmaj.ca/cgi/doi/10.1503/cmaj.080006

- Balter MS, Bell AD, Kaplan AG, et al. Management of asthma in adults. CMAJ www.cmaj.ca/cgi/doi/10.1503/cmaj.080007 